\title{
The Risks of Agile Methods in the Context of Digital Transformation
}

\author{
Teodora Elena Fogoroș ${ }^{1}$, Marieta Olaru², Gabriela Elena Bițan ${ }^{3}$ and Eleonora \\ Dijmărescu $^{4}$
}

1) 23344) The Bucharest University of Economic Studies, Bucharest, Romania.

E-mail: teodora.elena@icloud.com; E-mail: olaru.marieta@gmail.com

E-mail: gabriela_bitan@yahoo.com; E-mail: eleonora.harsan@gmail.com

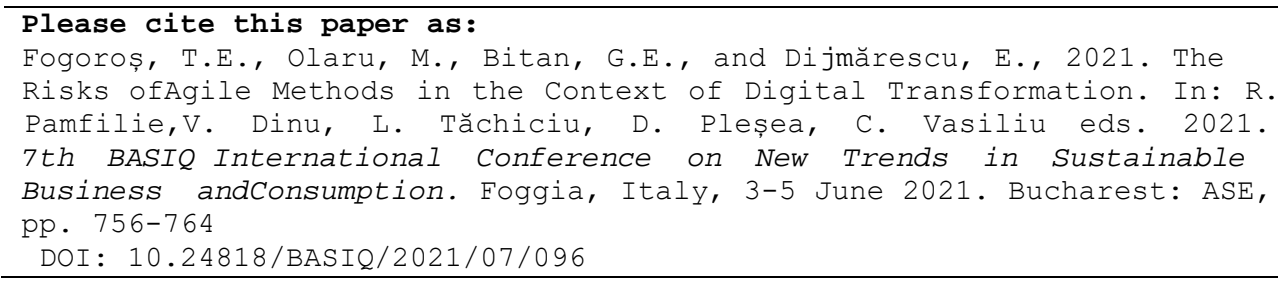

\begin{abstract}
This paper highlights the main elements of a doctoral research regarding the risks of agile methods in the context of digital transformation. The actual innovative times are conducting organizations to roll and improve their processes by using digital practices in an agile pattern. Turning projects teams to adapt agile methods in different scopes are aiming to improve the quality, to deliver excellent customer value and to drive velocity. If in the last years, innovation slowly entered the market, but it did not provide credibility that someday it will monopolize the organizational processes, the actual days are convincing skeptics that it is mandatory to digitalize the processes to compete the market. Therefore, organizations are strongly involved in the process of usage the agile methods. Though, one of the main project management activity is thought-out the risk management which in the agile methodology is related as well to risk prioritization. There are several risks areas that should be taken into consideration by projects teams before toiling the agile path. The aim of this study is to provide a theoretical framework for further studies on the risks of agile methods used by organizations, in the context of innovation usage. Based on a total of 100 publications, including recognized publishers, in this study we strive to provide a holistic overview on current risks of agile methods and possible risk prevention methods for organizations.
\end{abstract}

Keywords: Agile methods, agility risks, digital transformation, organizational innovation.

DOI: $10.24818 / B A S I Q / 2021 / 07 / 096$

\section{Introduction}

Reduced costs, reduced time, reduced risks, process simplification, value prioritization and quality improvement are some often encountered keywords in organizations' processes, so they align with the continuous improvement criteria. As today business environments are perceived as ultra-dynamic and hyper competitive, being agile is not considered anymore as optional, but needed to adapt its strategies and to provide successful actions (Ravichandran, 2018). Unlimited internet connection offers to clients the possibility to identify instantly better restaurants, better hotels and better services by a single phone touch (Fogoros, et al., 2020). Agility offers to the client structured deliverables, transparency, communication, swiftness and reasonable prices. Over and above, teams using agile methods are regrouping on a regular basis, daily or weekly, so they are continuously challenged: some demands become far-reaching or involves new ones to prioritize. They are prepared every time to schedule changes and push to other functionalities, by quickly reacting to scope. In this way, the value-based prioritization is one of the main capacities of this teams. Hence, not a single change is easy; clearly, people are used to traditional approaches and may be reticent to use other methodologies than the ones 
known so far. This is why adopting agility in organizations can be a sensitive and risky process to implement.

One of the fundamentals of project management activities is represented by the risk management. Though, once starting using agile methods in different activities, risk prioritization must be taken into consideration as well. If not correctly managed since the beginning, a project may encounter issues right before it starts. All teams should first understand the agile methods and its possible impact before starting using it, by considering a plan to alleviate risks (McGee, 2014). Based on the project's characteristics, the agile teams may have different size and departments involved, which raises different dilemmas: deteriorated productivity due to long meetings or communication gaps due to different spoken languages.

Based on statistics provided by the Project Management Institute in 2017, the agile methods have been integrated in organizations on a percentage of $71 \%$ (Project Management Institute, 2017), as observed in Figure 1.

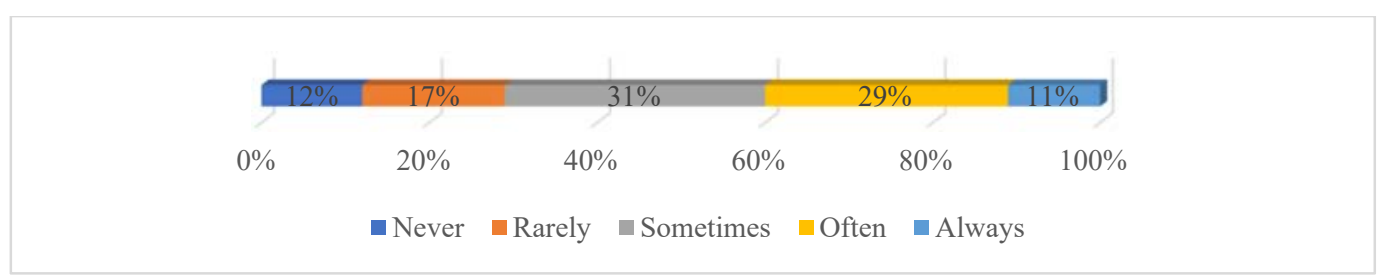

Figure no. 1. Agile approaches in organizations

Source: Project Management Institute, 2017. [online] Available at: <https://www.pmi.org//media/pmi/documents/public/pdf/learning/thought-leadership/pulse/pulse-of-the-profession-2017.pdf>

[Accessed 20 March 2021]

Though considered by several senior executives that agility is a key to success, 2018's statistics showed that agile has not fully spread throughout organizational processes. It is considered that one of the reasons would be the lack of official line up in risk management protocols, opposite of the traditional waterfall risk management procedures, which are more proper. Agility offers continuous improvement and change, but sometimes these often-considered strengths of processes, may turn out as being risky. Risks are often considered as a reason of alert, but it's not the risk itself the controversy point but its management strategy. As specified by Cagan, M. (2008) in her research, risk is a needed element in the innovation processes: the project and product owners should encourage up to a certain point risktaking among teams or at least consider the possible advantages of it before the final decision. There is not a specific definition for agility, but researchers tend to rely on it to market determinants and challenges, such as IoT (Internet of Things), innovation, digitalization, sustainability and technology (Skare and Soriano, 2021) and to consider it as part of an organization's success. Turning an organization into an agile one means to provide first several skills, such as a clear vision, a governance and a strategic planning. It is considered that committing people in several organizational restructuring processes, they are more likely to create systems based on people needs who are aiming to be open to change and to new learning approaches (Skare and Soriano, 2021). It represents the process of removing agility barriers, such as eliminating complex rules, to allow greater flexibility (Hoelbeche, 2019). Agility is not only related to organizational processes, but to human being as well. In everything people use to do as employees or as humans, agility should be present in everything we do. Using agile methods while developing a software between a company is indeed a good idea to quickly react and respond to the client's needs. Though, letting someone else take the place to the checkout while arranging your products on the tape at the supermarket is also defined agility. So, people must adopt agile reactions in everything they do. Undoubtedly, companies can no longer afford to work on a specific project for years - the current dynamic times we are facing may suddenly change the client's needs so the product developed at the end will no longer represent a current need.

In their research, Bris and Caballero (2015) defined firm's agility as a determinant of specific organization capability and regional/industry level factors. Innovation and digitization brought fast and unexpected changes, each of them turning into challenges for organizations on the market. Hence, agility must seem redundant in a business environment which focus is risk-only. Nowadays businesses 
are facing multiple categories of risks: business continuity risks, compliance risks, e-commerce risks, financial risks or fraud risks. In their research, Marquardt, et al. (2018) specified that the lack of IT skills of the employees and the availability of specialists is the biggest obstacle in the alignment with digitalization projects. Consequently, organizations are struggling to offer responses for all this risks, such as: risk avoidance (by eliminating the cause), controlling (reducing the consequences by severity of impact), acceptance (problem-solving oriented organizational culture) and allocation (insurance or subcontracting). In reverse, the usage of agile methods brings transparency, collaborative planning and customer involvement. Though, none of the above should reject the other. It is often considered that traditional risk management and the agile methods' risks are complimentary.

\section{Review of the scientific literature}

\section{Digital transformations in organizations}

To stay competitive, organizations are nowadays continuously challenged by digital technology, as implementing robust digital tools is crucial to stay on the market. Moreover, digital transformation affects the business structures by implementing a new playing field and changing the competitivity of firms on various levels (Grab et al., 2019). Fast actions, adaptability and digital practices implementation are elevating the hole industry. Anticipations made by Accenture in a survey report (Awalegaonkar, 2019), shows that by 2022, strategic scaling will be imperative to success. The predictions shows that $40 \%$ of industrial organizations will adopt IoT and artificial intelligence, $83 \%$ of executives confirm that the growth objectives won't be achieved without scaling to AI and $75 \%$ of organizations considers they risk going out of business in the next years if they don't scale to (Awalegaonkar, 2019). In the latest research on the concept of digitization and innovation it was concluded that an innovation process that constraints the contribution of several stakeholders are turning into the principal source of sustainable development (Meselu and Berhan, 2020). Even if digital technologies are the departure point for process innovation, other factors such as customer's expectations and digital competitors are very important. Furthermore, traditional business models are as well influenced by technology in the global market: the hotel industry was suddenly replaced by Booking or AirBnb, the music industry is continuously challenge by Spotify and Starbucks was digitalized by offering the possibility to pay with their own card for gaining points and obtaining several benefits (Feroz, et al., 2021).

Digital transformation doesn't represent a single step designed to upgrade some organizational processes, but a process which includes fundamental changes, and which has the capability to create additional opportunities of improvement (Feroz, et al., 2021). It was also debated by Verhoef et al. (2019) in their study that digitization, digitalization and digital transformation should not be perceived as the same: while digitization means automated tasks, digitalization brings extension of digital components to product or service offerings and digital transformation includes the business model innovative criteria and digital platforms. Initially introduced in the manufacturing industry, 4.0 In the scientific literature, the fundamental design principals of 4.0 Industry are the following: decentralization, horizontal integration, interoperability, modularity, product and service individualization, real-time capability, service orientation, smart factory, smart product, vertical integration and virtualization. On the other side, there are the technology trends: advanced manufacturing, augmented and virtual reality, automation and industrial robotics, big data analytics, blockchain, cloud data and computing, internet of people, internet of services, internet of things, simulation and modelling and cybersecurity. Companies are adopting several sustainable and innovative business practices, such as artificial intelligence, IoT, big data analytics and blockchain. Between them, blockchain is considered a software with hyper potential to achieve sustainability in business and industrial practices (Leng, et al., 2020). It can increase the product life cycle, maximize the resource usage and contribute to increased sustainability (Esmaeilian, et al., 2020). In 2013, Bharadwaj et al. considered that organizational strategy is defined and accomplished by extracting digital resources to create differential value. Later in 2021, Kurtz, et al. mentioned that there is a gap of knowledge on archetypical strategic orientations concerning the ability of organizations to adapt.

Holding an optimistic view, digitization and innovation offers many opportunities for organizations to improve its processes, but as well to create sustainable product life cycles. As Maier, D. (2018) 
specified in his research, innovations are defined as new creations of economic significance, performed by organizations.

\section{Agile methods and agility usage in organizations}

Once introduced on the market, agile software development methodology was described as the opposite of the traditional waterfall model. The logic of agility offers a flexible approach, followed by a learning from failure, while waterfall stood in a rigorous process management (Fogoros, et al., 2020). As the traditional approach supposes a predefined model with planning based on a work classification structure with landmarks and work processes (Overhage and Schauderer, 2012), agile focuses on a process control based on meeting's clients' needs. As nowadays change is constant and brutal, agile methods are proposing three levels of planning: the release planning (basic strategic aspects), the sprint planning (operational details) and the daily scrum (daily meetings of members for tasks and current state of the project. In Table no.1, we observe the differences between agile methods and traditional methods.

Table no. 1. Opposite perspective between agile and traditional

\begin{tabular}{|l|l|l|l|l|l|l|}
\hline Method & Planning & Requirement & Documentation & Controlling & Collaboration & Reflection \\
\hline $\begin{array}{l}\text { method } \\
\text { metional } \\
\text { planned in } \\
\text { advance }\end{array}$ & $\begin{array}{l}\text { Landmark } \\
\text { beginning of } \\
\text { the project }\end{array}$ & $\begin{array}{l}\text { Fixed since the } \\
\text { the development } \\
\text { process }\end{array}$ & $\begin{array}{l}\text { Part of } \\
\text { achievement } \\
\text { is on team } \\
\text { members }\end{array}$ & $\begin{array}{l}\text { Tasks assigned } \\
\text { by the project } \\
\text { manager }\end{array}$ & $\begin{array}{l}\text { Discussions } \\
\text { only at the } \\
\text { end of the } \\
\text { project }\end{array}$ \\
\hline $\begin{array}{l}\text { is the base } \\
\text { process }\end{array}$ & $\begin{array}{l}\text { Constant talk } \\
\text { between clients } \\
\text { and editors }\end{array}$ & $\begin{array}{l}\text { Unequivocal } \\
\text { documentation }\end{array}$ & $\begin{array}{l}\text { Constant } \\
\text { meetings on } \\
\text { the progress }\end{array}$ & Flat hierarchy & $\begin{array}{l}\text { Continuous } \\
\text { communica } \\
\text { tion at the } \\
\text { end of each } \\
\text { sprint }\end{array}$ \\
\hline
\end{tabular}

Source: Overhage and Schlauderer, 2012

Agile methods are running from the philosophy of close, intermittent and compiled collaborations, having as main characteristics adaptive planning evolutionary development, flexibility in the face of changes and continuous communication (Akil Rafeek, 2019). In their research, Lopez-Alcarria, et al. (2019) specified that agile methods praise adaptive development by short and continuous cycles of planning, action, correction and adjustment to provide valuable outcomes. Hence, agility means an ability to respond to change. As noticed by Gannod, et al. (2015) in their article, a special emphasis is exhibited by agile methods on facilitating interactions and team dynamics, supporting collaboration between different departments, articulating goals and encouraging innovation and experimentation. In 2001, Fowler and Highsmith, for the first time, gathered together a team of 17 software developers and agile coaches and practitioners and managed together to define the manifesto for agile, as it follows: individuals and interactions over processes and tools, working software over comprehensive documentation, customer collaboration over contract negotiation, responding to change over following a plan.

Organizations are facing competitive times during the current uncertainty and turbulence in the business environment, so quickly answering to client's needs is the key to market dynamics. Agile methods presume quickness (fast answer to businesses and clients' needs), resources (people, technology, processes, knowledge) and adaptability (organization's flexibility). As there are multiple influencing factors on innovation processes, to apply the concept of agility to innovation requires a clear definition due to specificity. Brand, et al. (2021) in their article considers that the main three capabilities of agility (respond quickly, proactively drive change and integrate the environment) provide a basic understanding of it. Based on their research, the corporate strategy and the organizational system are in charge of shaping innovation between an organization (Brand, et al., 2021). Moreover, Ahlback, et al. (2017) noticed in their recent research that $81 \%$ of respondents on a survey observed an increased business performance once agility adopted. During a qualitative analysis, Walter (2020) identified four agility categories in the organizational agility: agility drivers, agility enablers, agility capabilities and agility dimensions. Though, agility should not be considered as a radical approach, which can apply or not, but rather as an integrated holistic concept, taking into account the organizational context and the business environment, as well as independent of the 
industry. Walter (2020), specified in her research that an agile organization is oriented both internally and externally. The perception difference is represented as it follows: on the internal orientation, the organization focuses on the coordination of agility categories, while on the external one, it shows a high level of vigilance on the competitive market and the environmental changes.

To conclude, the investment in the level of digitization of an organization, on RandD and design, new product development, market research and branding are considered the main determinants of an agile form (Skare and Soriano, 2021).

\section{Research methodology}

Considering as milestone a previous research in the agile lifecycle, where a study on the agile digital transformation in relation to organizational innovation was developed, this article proposes an empirical research based on the existing scientific literature, relied on statistics and results obtained before the possible future changes of the actual sanitary crisis. The aim of this study is to is to provide a theoretical framework for further studies on the risks of agile methods used by organizations, in the context of innovation usage. Based on a total of 100 publications, including recognized publishers and statistics at European level, in this study we strive to provide a holistic overview on current challenges of agility, risks encountered and recommendations for organizations. A step-by-step process of identification of articles and analyse was followed: selection of sources, search criteria settings (use of keywords), selection criteria (screening of the articles) and content analysis and synthesis (classification of articles based on theme).

\section{Results and discussion}

The unpredictable times companies are facing nowadays are conducting them to increase its level of flexibility, by applying methodologies that can answer to customers' requirements fast, cheap and safe. By definition, agility is fast, cheap, safe, comfortable and easy, when correctly implemented and understood by its users. Though, several risks such as less predictability, lack of innovation and decreased level of staff knowledge are identified in the scientific literature. This study adds a contribution for further studies on the risks of agile methods used by organizations, in the context of innovation usage. Based on a total of 100 publications, including recognized publishers, we strive to provide a theoretical framework on the risks of agile methods used in organizations followed by some prevention methods.

Table no. 2. Risks of agile methods

\begin{tabular}{|c|c|c|c|c|}
\hline Risk area & $\begin{array}{c}\text { Identified risk } \\
\text { of agile } \\
\text { methods } \\
\end{array}$ & $\begin{array}{l}\text { Source of } \\
\text { research }\end{array}$ & Authors' statement & Prevention methods \\
\hline \multirow[b]{2}{*}{ Demographics } & $\begin{array}{l}\text { Less } \\
\text { predictability }\end{array}$ & $\begin{array}{l}\text { Garbar, D., } \\
2020\end{array}$ & $\begin{array}{l}\text { Constant changes, no } \\
\text { long-term } \\
\text { predictions }\end{array}$ & $\begin{array}{l}\text { Project split in smaller phases, } \\
\text { requirement clarifications }\end{array}$ \\
\hline & $\begin{array}{l}\text { Time zone } \\
\text { differences, } \\
\text { local holidays, } \\
\text { training plans }\end{array}$ & $\begin{array}{l}\text { McGee, } \\
\text { T., } 2014\end{array}$ & $\begin{array}{l}\text { Iteration planning to } \\
\text { know the availability } \\
\text { of each team } \\
\text { member }\end{array}$ & $\begin{array}{l}\text { Find the best way to communicate } \\
\text { to facilitate work between } \\
\text { different time slots, alternate } \\
\text { meeting times }\end{array}$ \\
\hline \multirow{3}{*}{ Team skillset } & $\begin{array}{l}\text { Not sticking to } \\
\text { Agile } \\
\text { principles }\end{array}$ & $\begin{array}{l}\text { Garbar, D., } \\
2020\end{array}$ & $\begin{array}{l}\text { Agile usage while } \\
\text { following traditional } \\
\text { management } \\
\text { principles }\end{array}$ & $\begin{array}{l}\text { Guide the clients, teach them to } \\
\text { apply the appropriate principles }\end{array}$ \\
\hline & $\begin{array}{l}\text { Lack of staff } \\
\text { knowledge }\end{array}$ & $\begin{array}{l}\text { Garbar, D., } \\
2020\end{array}$ & $\begin{array}{l}\text { Agile training } \\
\text { investment needed }\end{array}$ & $\begin{array}{l}\text { Support knowledge sharing and } \\
\text { mentoring practices }\end{array}$ \\
\hline & $\begin{array}{l}\text { Decreased } \\
\text { productivity }\end{array}$ & $\begin{array}{l}\text { McGee, } \\
\text { T., } 2014\end{array}$ & $\begin{array}{l}\text { Large Scrum teams } \\
\text { increase the time }\end{array}$ & Work with small Scrum sub-teams \\
\hline
\end{tabular}




\begin{tabular}{|c|c|c|c|c|}
\hline & & \multicolumn{3}{|c|}{ New Trends in Sustainable Business and Consumption } \\
\hline & & & $\begin{array}{l}\text { spend in meetings } \\
\text { and decrease } \\
\text { productivity }\end{array}$ & \\
\hline & $\begin{array}{l}\text { Dispersed team } \\
\text { members }\end{array}$ & $\begin{array}{l}\text { McGee, } \\
\text { T., } 2014\end{array}$ & $\begin{array}{l}\text { Working face-to-face } \\
\text { helps to identify the } \\
\text { best methods of } \\
\text { work }\end{array}$ & $\begin{array}{l}\text { Often co-location of teams for } \\
\text { even a short timeframe }\end{array}$ \\
\hline & $\begin{array}{l}\text { Lack of early } \\
\text { gap } \\
\text { acknowledge }\end{array}$ & $\begin{array}{l}\text { McGee, } \\
\text { T., } 2014\end{array}$ & $\begin{array}{l}\text { Gaps from both } \\
\text { technical and agile } \\
\text { should be observed } \\
\text { at the beginning }\end{array}$ & $\begin{array}{l}\text { Provide specialized training and } \\
\text { time to achieve abilities }\end{array}$ \\
\hline & $\begin{array}{l}\text { Not co-locate } \\
\text { team members } \\
\text { by discipline or } \\
\text { role }\end{array}$ & $\begin{array}{l}\text { McGee, } \\
\text { T., } 2014\end{array}$ & $\begin{array}{l}\text { Look to collocate } \\
\text { similar skillsets team } \\
\text { members }\end{array}$ & $\begin{array}{l}\text { The product owner and the } \\
\text { business analyst may increase } \\
\text { partnering chances }\end{array}$ \\
\hline & $\begin{array}{l}\text { Not pairing } \\
\text { senior team } \\
\text { members }\end{array}$ & $\begin{array}{l}\text { McGee, } \\
\text { T., } 2014\end{array}$ & $\begin{array}{l}\text { Identify team } \\
\text { members with } \\
\text { specific technical } \\
\text { skillsets }\end{array}$ & $\begin{array}{l}\text { Usage of pair-programming } \\
\text { method }\end{array}$ \\
\hline & $\begin{array}{l}\text { Lack of } \\
\text { AgileMaster }\end{array}$ & $\begin{array}{l}\text { McGee, } \\
\text { T., } 2014\end{array}$ & $\begin{array}{l}\text { Coaches have a deep } \\
\text { understanding of } \\
\text { agile methods }\end{array}$ & $\begin{array}{l}\text { Coaches can be internal or external } \\
\text { and can help the team ramp up } \\
\text { more quickly }\end{array}$ \\
\hline \multirow{5}{*}{ Culture } & $\begin{array}{l}\text { Agile is not } \\
\text { suitable for a } \\
\text { project }\end{array}$ & $\begin{array}{l}\text { Garbar, D., } \\
2020\end{array}$ & $\begin{array}{l}\text { The need for a clear } \\
\text { scope, a clear } \\
\text { requirement, fixed } \\
\text { budget }\end{array}$ & $\begin{array}{l}\text { Use another more profitable } \\
\text { approach }\end{array}$ \\
\hline & $\begin{array}{l}\text { Not recognize } \\
\text { or adjust to } \\
\text { different } \\
\text { cultures }\end{array}$ & $\begin{array}{l}\text { McGee, } \\
\text { T., } 2014\end{array}$ & $\begin{array}{l}\text { Cultural differences } \\
\text { play into project's } \\
\text { dynamics, some } \\
\text { cultures are more } \\
\text { vocal than others }\end{array}$ & $\begin{array}{l}\text { Team members must understand } \\
\text { an individual's organizational } \\
\text { culture }\end{array}$ \\
\hline & $\begin{array}{l}\text { No } \\
\text { transparency }\end{array}$ & $\begin{array}{l}\text { Buganova, } \\
\text { K. and } \\
\text { Šimíčková, } \\
\text { J., } 2019\end{array}$ & $\begin{array}{l}\text { Not revealing the } \\
\text { errors }\end{array}$ & $\begin{array}{l}\text { Regularly information about } \\
\text { possible errors }\end{array}$ \\
\hline & $\begin{array}{l}\text { Absence of } \\
\text { basic agile } \\
\text { education } \\
\text { between } \\
\text { managers }\end{array}$ & $\begin{array}{l}\text { McGee, } \\
\text { T., } 2014\end{array}$ & $\begin{array}{l}\text { Management should } \\
\text { know the agile } \\
\text { benefits and its } \\
\text { possible impacts to } \\
\text { the organizations }\end{array}$ & $\begin{array}{l}\text { Training provided for management } \\
\text { team }\end{array}$ \\
\hline & $\begin{array}{l}\text { Lack of } \\
\text { communication } \\
\text { with the clients }\end{array}$ & $\begin{array}{l}\text { McGee, } \\
\text { T., } 2014\end{array}$ & $\begin{array}{l}\text { Customers should be } \\
\text { part of the process } \\
\text { development }\end{array}$ & $\begin{array}{l}\text { Daily communication with } \\
\text { customers which can prioritize the } \\
\text { backlog evolutions }\end{array}$ \\
\hline \multirow{2}{*}{$\begin{array}{c}\text { Supplier } \\
\text { dependencies }\end{array}$} & Budget risks & $\begin{array}{l}\text { Garbar, D. } \\
2020\end{array}$ & $\begin{array}{l}\text { Agile methods } \\
\text { assume constant } \\
\text { changes of the } \\
\text { product related to } \\
\text { market needs }\end{array}$ & Lean development to manage costs \\
\hline & $\begin{array}{l}\text { Unexpected } \\
\text { delays }\end{array}$ & $\begin{array}{l}\text { McGee, } \\
\text { T., } 2014\end{array}$ & $\begin{array}{l}\text { Sometimes the } \\
\text { development is } \\
\text { completed earlier, } \\
\text { but implemented in } \\
\text { future release }\end{array}$ & Stay engaged with suppliers \\
\hline
\end{tabular}




\begin{tabular}{|c|c|c|c|}
\hline Technical debt & $\begin{array}{l}\text { Garbar, D., } \\
2020\end{array}$ & $\begin{array}{l}\text { Many changes which } \\
\text { lead to low system } \\
\text { performance }\end{array}$ & $\begin{array}{l}\text { Clarify at the very beginning the } \\
\text { non-functional requirements } \\
\text { related to performance quality }\end{array}$ \\
\hline $\begin{array}{l}\text { Not-added } \\
\text { value }\end{array}$ & $\begin{array}{l}\text { Buganova, } \\
\text { K. and } \\
\text { Šimíčková, } \\
\text { J., } 2019 \\
\end{array}$ & $\begin{array}{l}\text { Later usage of the } \\
\text { product or its } \\
\text { prototype }\end{array}$ & $\begin{array}{l}\text { In order to make money sooner, } \\
\text { the usage should start as soon as } \\
\text { possible }\end{array}$ \\
\hline $\begin{array}{l}\text { Not adequately } \\
\text { monitoring } \\
\text { schedule, cost } \\
\text { and scope } \\
\text { variables }\end{array}$ & $\begin{array}{l}\text { Nguyen, } \\
\text { D.S., } 2016\end{array}$ & $\begin{array}{l}\text { Some developments } \\
\text { fail because of } \\
\text { project managers } \\
\text { which are not } \\
\text { following all the } \\
\text { variables }\end{array}$ & $\begin{array}{l}\text { Leaders must be cognizant of } \\
\text { organizational issues: motivation, } \\
\text { team synergy, etc. }\end{array}$ \\
\hline $\begin{array}{l}\text { Market's } \\
\text { feedback }\end{array}$ & $\begin{array}{l}\text { Berg et al., } \\
2020\end{array}$ & $\begin{array}{l}\text { Level of } \\
\text { understanding of } \\
\text { agile methodology }\end{array}$ & Continuous communication \\
\hline $\begin{array}{l}\text { Third-party } \\
\text { vendors }\end{array}$ & $\begin{array}{l}\text { Berg et al., } \\
2020\end{array}$ & $\begin{array}{l}\text { Adoption of tools } \\
\text { and components }\end{array}$ & Written agreements on services \\
\hline Uncertainty & $\begin{array}{l}\text { Tavares et } \\
\text { al., } 2019\end{array}$ & $\begin{array}{l}\text { Possible event that } \\
\text { can affect the } \\
\text { product }\end{array}$ & Continuous surveillance \\
\hline Rare deliveries & $\begin{array}{l}\text { Tavares et } \\
\text { al., } 2019\end{array}$ & $\begin{array}{l}\text { The customer will } \\
\text { lose trust in the } \\
\text { product }\end{array}$ & Make frequent deliveries \\
\hline $\begin{array}{l}\text { Quality of } \\
\text { outsourced } \\
\text { partners }\end{array}$ & $\begin{array}{l}\text { Berg et al., } \\
2020\end{array}$ & $\begin{array}{l}\text { Outsourced manual } \\
\text { testing }\end{array}$ & $\begin{array}{l}\text { Offer staff flexibility, develop } \\
\text { internal staff and focus on core } \\
\text { tasks }\end{array}$ \\
\hline
\end{tabular}

Source: Authors own research

In Figure 2 we observed the tendency of publishing scientific articles containing "agile risks" and "agile" as keywords, with a clear vision of the fact that 2020 represented the year when agility managed to penetrate the organizational processes, based on ScienceDirect. Indeed, in the pandemic context, agility was present in most organizational processes.

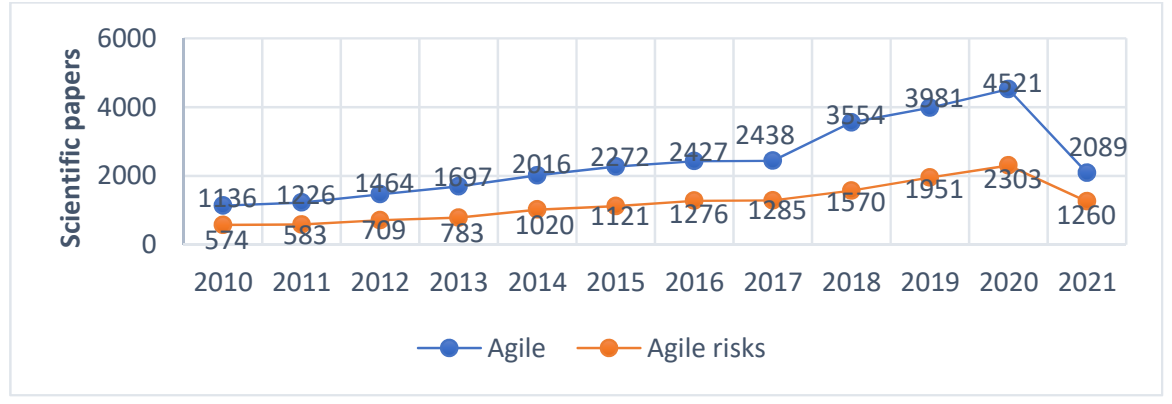

Figure no. 2. Scientific papers publishment tendency on agile Source: Elaborated by the authors

\section{Conclusions}

Based on the research results, this paper concludes that there are four main categories of agile methods risks identified in the scientific literature: demographics, team skillset, culture and supplier dependencies. Indeed, lack of knowledge and supplier dependencies are situated on the top. Agile 
methods started to be used in organizations since 2000 , but only in the latest years its importance increased in process' organizations; as observed before, 2020 represented the year when most of the authors started to invest time in agility's research. Clearly, in the pandemic context, all activity domains were affected, due to daily changes and unpredictable situations, so being agile was a mandatory adoption. The client's demand had to be rapidly answered and following a traditional methodology didn't represent anymore an option. We aim that this study will help organizations to prevent a part of the risks associated with agile methods grace to the preventing methods proposed, before adopting it in their processes, as adapting to challenges brought by digitization is nowadays necessary.

\section{References}

Ahlback, K., Fahrbach, C., Murarka, M. and Saolo, O., 2017. How to create an agile organization. McKinseyand Company Organization. [online] Available at: $<$ https:/www.mckinsey.com/business-functions/organization/our-insights/how-to-create-an-agileorganization $>$ [Accessed 5 April 2021].

Akil Rafeek, M., Arbain, A.F. and Sudarmilah, E., 2019. Risk mitigation techniques in agile development processes. Int.J.Sup.Chain.Mgt., 8(2), pp. 1123-1129.

Awaleganokar, K., Berkey, R., Douglass, G. and Reilly, A., 2019. AI: Built to scale. Survey Report. [pdf] Accenture Life Sciences. Available at: <https://www.accenture.com/_acnmedia/ThoughtLeadership-Assets/PDF-2/Accenture-Built-to-Scale-PDF-Report.pdf $>$ [Accessed 5 April 2021].

Berg, V., Birkeland, J., Nguyen-Duc, A., Pappas, I.O. and Jaccheri, L., 2020. Achieving agility and quality in product development - an empirical study of hardware startups. The Journal of Systems and Software, 167, Article number: 110599.

Bharadwaj, A., El Sawy, O.A., Pavlou, P.A. and Venkatraman, N., 2013. Digital Business Strategy: Toward a Next Generation of Insights. MIS Quarterly, 37(2), pp. 471-482.

Brand, M., Tiberius, V., Bican, P.M. and Brem, A., 2019. Agility as an innovation driver: towards an agile front. Review of Managerial Science, 15(1), pp.157-187.

Bris, A. and Caballero, J., 2015. IMD World competitiveness center, Company agility and competitiveness, [online] Available at: <https://www.imd.org/researchknowledge/articles/com_june 2015/\#: : text=Essential $\backslash \% 20$ to $\backslash \% 20$ business $\backslash \% 20$ efficiency $\backslash \% 20$ is, lead $\backslash \% 20$ to $\backslash$

$\% 20$ sustainable $\ \% 20$ value $\ \% 20$ creation $>$ [Accessed 21 March 2021].

Buganova, K. and Šimíčková, J., 2019. Risk management in traditional and agile project management. Transportation Research Procedia, 40, pp. 986-993.

Cagan, M., 2008. Empowered: Ordinary people, extraordinary products. John WileyandSons.

Esmaeilian, B., Sarkis, J., Lewis, K. and Behdad, S., 2020. Blockchain for the future of sustainable supply chain management in Indsutry 4.0. Resour. Conserv. Recycl., 163, Article number: 105064.

Feroz, A.K., Zo, H. and Chiravuri, A., 2021. Digital transformation and environmental sustainability: a review and research agenda. Sustainability, 13(3), Article number: 1530.

Fogoros, T., Maftei, M., Olaru, S.M. and Bitan, G.E., 2020. From traditional to digital: a study on business models in the context of digitization. Proceedings of the $3^{\text {rd }}$ International Conference on Economics and Social Sciences, pp.749-757.

Fogoros, T.E., Olaru, S.M., Trifan, B.I. and Dorin, M., 2020. Study on agile digital transformation in relation to organizational innovation. Proceedings of the $36^{\text {th }}$ IBIMA Conference: 4-5 November 2020, Granada, Spain.

Fowler, M. and Highsmith, J., 2001. The agile manifesto, [online] Available at: $<$ https://agilemanifesto.org/iso/en/manifesto.html> [Accessed 25 March 2021].

Gannod, G.C., Troy, D.A., Luczaj, J.E. and Rover, D.T., 2015. Agile way of educating. Proceedings of the 2015 IFEE Frontiers in Education Conference (FIE), Washington, D.C., USA, 21-24 October 2015, pp.1-3. 
Garbar, D., 2020. Common risks in agile projects and how to prevent them, [online] Available at: $<$ https://belitsoft.com/custom-application-development-services/agile-methodology $>$ [Accessed 5 April 2021].

Grab, B., Olaru, M. and Gavril, R.M., 2019. The impact of digital transformation of strategic business management. Ecoforum Journal, 8(1), pp.1-8.

Hoelbeche, L., 2019. Designing sustainably agile and resilient organizations. Syst.Res.Behav.Sci., 36(5), pp.668-677.

Kurtz, H., Hanelt, A. and Kolbe, L.M., 2021. Exploring strategic orientations in the age of digital transformation: a longitudinal analysis of digital business model patterns. Proceedings of the 16th International Conference on Wirtschaftsinformatik, Essen, German.

Leng, J., Ruan, G., Jiang, P., Xu, K., Liu, Q., Zhou, X. and Liu, C., 2020. Blockchain-empowered sustainable manufacturing and product lifecycle management in industry 4.0: A survey. Renew.Sustain.Energy.Rev., 132, Article number: 110112.

Lopez-Alcarria, A., Olivares-Vicente, A. and Poza-Vilches, F., 2019. A systematic review of the use of agile methodologies in education to foster sustainability competencies. Sustainability, 11, Article number: 2915.

Maier, D., 2018. Product and process innovation: a new perspective on the organizational development. International Journal of Advanced Engineering and Management Research, 3(6), pp.132-138.

Marquardt, K., Olaru, M., Golowko, N. and Kiehne, J., 2018. Study on economics trends, drivers and developments of the $21^{\text {st }}$ century. Proceedings of BASIQ International Conference on New Trends in Sustainable Business and Consumption, pp.65-73.

Mcgee, T., 2014. Going agile? How to reduce your risk of failure. PMI Global Congress - North America, Phoenix, AZ. Newton Square, PA: Project Management Institute.

Meselu, S.T. and Berhan, E., 2020. Meta-systematic review on business model innovation studies. International Journal Business Innovation and Research, doi: 10.1504/IJBIR.2020.10030935.

Nguyen, D.S, 2016. Success factors that influence agile software development project success. American Scientific Research Journal for Engineering, Technology and Sciences, 17(1), pp.172222.

Overhage, S. and Schlauderer, S., 2012. How sustainable are agile methodologies? Acceptance factors and developer perceptions in scrum projects. Proceedings of ECIS, 8, http://aisel.aisnet.org/ecis2012/8.

Project Management Institute, 2017. Success rates rise, transforming the high cost of low performance. PMI's Pulse of the profession, 9th Global Project Management Survey. [pdf] Available at: $<$ https://www.pmi.org/-/media/pmi/documents/public/pdf/learning/thoughtleadership/pulse/pulse-of-the-profession-2017.pdf> [Accesses 20 March 2021].

Rafeek, M.A., Arbain, A.F., Sudarmilah, E., 2019. Risk mitigation techniques in agile development processes. International Journal of Supply Chain Management., 8(2), pp.2051-3771.

Ravichandran, T., 2018. Exploring the relationships between IT competence, innovation capacity and organizational agility. Journal of strategic information systems, 27(2018), pp.22-42.

Škare, M. and Soriano, D.R., 2021. A dynamic panel study on digitalization and firm's agility: What drives agility in advanced economies 2009-2018. Technological Forecasting and Social Change, 163, Article number: 120418.

Tavares, B.G., Sanches da Silva, C.E. and Diniz de Sourza, A., 2019. Practices to improve risk management in agile projects, International Journal of Software Engineering, 29(2), pp.1-19.

Walter, A.T., 2020. Organizational agility: ill-defined and somewhat confusing? A systematic literature review and conceptualization. Management Review Quarterly, 71, pp.343-391. 